\title{
Discourses of objection: towards an understanding of third-party rights in planning
}

\section{Geraint Ellis}

School of Environmental Planning, Queen's University, Belfast, David Keir Building, Stranmillis Road, Belfast BT9 5AG, Northern Ireland; e-mail: g.ellis@qub.ac.uk

Received 17 July 2003; in revised 29 December 2003

\begin{abstract}
Public participation is central to the practice, legitimacy, and dominant normative principles of spatial planning. It has a strong presence in the discourse of communicative governance, which suggests that participatory rights should be strengthened as part of a systematic institutional design. Interest in the concept of rights within planning has been gathering pace, but is still undeveloped. In terms of third-party rights, attention has been focused on citizens as rights claimants and their use of rights to promote self-interest, rather than the values that should be protected by such rights or the balance of rights between different stakeholders. This paper explores some of the theoretical issues related to third-party rights in planning, using the existing literature on planning disputes to contextualise current debate. It examines a case study of third-party appellants in the Republic of Ireland and identifies five distinct 'discourses of objection'. These discourses highlight the complex factors that stimulate third-party rights-claims and illustrate how they can be related to issues such as citizenship, the public interest, and property rights. The paper concludes with a number of general observations on the nature of rights in planning and the implications this has for the broader paradigm of communicative governance.
\end{abstract}

\section{Introduction}

Public participation has been one of the most debated concepts in planning for decades and is central to the goals, practice, and legitimation of land-use regulation. Much effort has been placed on researching the rationale, effectiveness, and fairness of participation (for example, Campbell and Marshall, 2000; Davies, 2001; Fagence, 1977; Hague et al, 2003; Thomas, 1996). This paper does not rehearse the main dimensions of this debate, but seeks to link perspectives on participation with the growing interest in the concept of rights in planning. The interest in planning and rights is reflected both in theory, with Healey (1997) seeing an enhanced rights regime as contributing to the systematic institutional design for collaborative planning, and in practice, through the impact of the Human Rights Act 1998 (HRA), which has questioned the established relationships between public and private interests (Crow, 2001; Grant, 2000). Although some of the legal-administrative implications of the HRA are beginning to be resolved through the courts (for example, Finlay and Bird, 2002; Maurici, 2002; 2003), the broader moral and political consequences of increased 'rights talk' in planning are only slowly beginning to be addressed (for example, Alexander, 2002a; Ellis, 2000; Low and Gleeson, 1999; Miller, 1998).

A focus on rights in planning also raises particular issues for the theory and practice of public participation in that it questions the balance between law and democracy and between individual and collective interests. Recent studies on participation practice (Bedford et al, 2002; Campbell and Marshall, 2000; Hillier, 2003) have questioned whether participation outcomes are always beneficial for the public interest, suggesting that the dominance of certain interests, an emphasis on short-term demands, and the reproduction of existing power structures act against the collective good. These have contributed to an implicit assumption, readily supported by property interests, that any enhanced rights regime would accentuate such problems and create administrative chaos. 
It is argued here that such a view has developed without evidence from instances of rights claims and is based on simplified notions of why individuals object to development.

This paper attempts to clarify some of the issues related to third-party rights in planning, first by reviewing the role of rights in planning by using existing literature on planning disputes to contextualise current academic debate. It then analyses the attitudes of a group of individuals exercising their right to make a third-party appeal in the Republic of Ireland. This identifies five distinct 'discourses of objection' that highlight the complex range of motivational factors for why third parties make rights claims against proposed development. Reflecting on this case study, the paper makes a number of observations on rights and participation in planning and suggests that academic attention on the procedural outcomes of enhanced rights regimes has been to the neglect of understanding how rights could be used to enshrine important normative principles in the planning process.

\section{The notion of rights}

The notion of rights provides a powerful shaping force in Western liberal democracies with origins drawing on a wide provenance that includes natural law, divinity, and positivism (Shestack, 1998), shaped by varying interpretations over many centuries (see Buergenthal, 1997; Weissbrodt, 1988). Rights have strong rhetorical appeal and have provided persuasive moral backing to some of the key political movements of the last century, including the abolition of slavery, protection of minorities, universal suffrage, and trade unionism (Weston, 1984). Despite there being few alternative vocabularies through which similar claims can be made, there has been intense debate on the value of rights as a political concept. On the one hand, protagonists view rights as being of central importance to society (for example, Cranston, 1973), environmental protection (for example, Boyle and Anderson, 1996; Eckersley, 1996; Hancock, 2003), and justice (for example, Young, 1990) and as having radical potential as their strict enforcement, "would entail massive and in some ways, revolutionary transformations in the political-economy of capitalism" (Harvey, 2000, page 90). Critical voices have also presented powerful arguments, with some claiming that rights have been used to sustain rather than challenge power (Stammer, 1993) and accentuate current patterns of privilege (Low and Gleeson, 1999) to provide a 'liberal illusion' that implies equality and empowerment but in reality provides mystification for the status quo (Benton, 1993). A general theory of rights has been produced by Freeden (1991), who suggests that a right is best thought of as a 'protective capsule' for certain attributes that society wishes to assign with particular priority. Thus, the importance of the European Convention of Human Rights (ECHR) does not derive from its mere existence, but because it places essential value on protecting citizens from torture, state tyranny, etc. The critical significance of this view is that it emphasises the attributes the right encompasses and the prioritisation of encapsulated values, rather than focusing on the merits of rights as a mechanism for social or political organisation.

Any discussion of rights will tap into deeply held philosophical and sociological beliefs and will tend to reflect ideological positions on citizenship and the state, with distinct conceptions held by liberal, libertarian, republican, and communitarian viewpoints (Etzioni, 1995; Miller, 1995; Searing et al, 2003). It must also be acknowledged that not only can rights be interpreted in terms of differing political claims, but they are also seen by some as offering a distinctive ethical approach (Mackie, 1984), distinguished from those based on duty (O’Neill, 2000; Paton, 1948), virtue (Pence, 1993), and outcomes or consequences. The distinction between consequentialist ethics and those based on rights is particularly significant for planning, as utilitarianism has been 
a recurrent theme for the justification of planning decisions (Alexander, 2002b; Campbell and Marshall, 2002; Taylor, 1994) and has been shown to be the most significant ethical framework for planners in the USA (Howe, 1994). A rights approach may provide a fundamentally different ethical perspective on planning decisions, including an emphasis on the distribution of costs rather than the aggregated benefits, as proposed by utilitarianism. As such, rights can be seen by liberalism as being "political trumps", to be used by citizens "when a collective goal is not a sufficient justification for denying them what they wish as individuals to have or to do, or not a sufficient justification for imposing some loss or injury upon them" (Dworkin, 1984, page xi). This suggests an increased emphasis on rights could lead to a more fundamental questioning of current planning theory and practice than has so far been envisaged.

Because of the plurality of understanding of what we mean by 'rights', it is important to acknowledge that they can be seen as being both 'positive', requiring others to take action to benefit the rights holder, or 'negative', protecting the rights holder from arbitrary interference (Goodin, 1985). Rights may also exist in forms that can be upheld by law and therefore be defended legally (Stone, 1974) and those that are essentially culturally defined morals. Furthermore, legally defined rights may aim to secure safeguards over both process (that is, procedural rights) and outcomes (that is, substantive rights). Of particular interest in this paper are legally defined procedural rights, as Anglo-Irish planning law tends to be dominated by process rather than outcomes (Grant, 2000; Herling and Purdue, 2000). This is not to deny, however, that other forms of rights may significantly frame the way in which individual stakeholders interact in the planning process.

The contested nature of rights is reflected in the lack of coherence in the way the concept has been considered within a variety of planning contexts. For example, rights have been utilised as a way of understanding ethical influences on planners (Howe, 1994), as an evaluation tool (Alexander, 2002a), and as a mechanism to claim justice for marginalised groups (Berke et al, 2002; Imrie, 1996) or countryside access (Parker, 1999; Parker and Ravenscroft, 2001). Rights have also been used as a medium for assessing the interaction of property interests and land-use regulation (for example, Harrison, 1987, Krueckeberg, 1995; McAuslan, 1980; Pearce, 1981) and utilised as part of a critique of the concept of planning itself (for example, Corkindale, 1999; Lai, 1997; Pennington, 2000). In recent years, however, the most dominant perspective in the United Kingdom has been one of legal positivism that locates the impact of rights firmly within the realm of the law and statutory-derived procedures (for example, Crow, 2001; Grant, 2000; Hart, 2000; Loveland, 2001), while the potential of rights as a basis for environmental legislation (Hayward, 2000) has been largely overlooked.

Healey (1997) has provided a more abstract view of the role of rights in her thesis for collaborative planning, locating rights within an institutionalist framework that relates to communicative action and structuration. Here she distinguishes the "hard infrastructure' of formal organisational structures, laws, etc and the 'soft infrastructure' made up of social relations, administrative routines, professional cultures, etc. Healey identifies rights as part of hard infrastructure that frame specific instances of activity, so that the way rights are formally specified, distributed, and redeemed has a significant effect on structuring power relations and governance practices. Healey identifies four sets of rights that relate to participation: rights to 'voice', 'influence', 'information', and 'challenge'. In her normative vision for planning, Healey particularly emphasises the last of these, as it acts as a safeguard both against unreasonable infringements of private interests and against failures to provide adequate information or properly acknowledge the diversity of interests at stake in any decision. Healey appreciates that an enhanced rights regime on its own cannot secure such values but needs to be accompanied and 
mediated through a revised approach to planning practices, governance, resource allocation, and competences. From this perspective, rights have an acknowledged place within more open and inclusive forms of planning as a way of encapsulating some of the values that should be central to discursive processes. Dryzek (1990) has also suggested that direct action to assert both procedural and substantive rights over prolonged periods of time can force agencies of the state to adopt practices that are more conducive to communicative governance (see also Sanderson, 1999).

\section{Rights and participation}

The relatively simple objective of public participation in planning as being "about acting on the belief that everyone should know they can influence the shape of their community" (Bedford et al, 2002, page 312) hides the complexity of a process that involves a vast diversity of intents and differentials of power between the stakeholders involved. Campbell and Marshall (2000) offer a conceptual means of understanding some of these issues by typifying underlying motivations into five rationales for participation:

(1) instrumental participation - an emphasis on individuals expressing self-interest;

(2) communitarian participation - priority placed on collective well-being;

(3) politics of the consumer - stressing freedom of choice and individual preferences;

(4) politics of presence-an emphasis on promoting the needs of excluded groups;

(5) deliberative democracy - priority placed on inclusiveness and open dialogue.

Campbell and Marshall (2000) emphasise the importance of the nature of the interests served by each rationale, noting that all but the last place a strong emphasis on the articulation of a set of rights, although the nature of these varies for each perspective. For example, instrumental participation stresses basic rights to express and pursue self-interest whereas communitarian participation emphasises collective rights. Only the fifth approach, deliberative democracy, does not readily identify with a rights agenda, but emphasises the process of decisionmaking rather than the interests served, although it is noted above that Healey (1997) regards strengthened rights of challenge as being an important institutional element for more collaborative forms of planning.

These five rationales provide a useful context for highlighting some of the tensions between concepts of rights and participation. These tensions are represented on the one hand by the pervasive professional and political idea of maximising citizen involvement in the planning process through discursive practice and on the other by a number of recent studies that indicate that participatory practice often fails to live up to its theoretical ideals. The ideas behind collaborative planning are well rehearsed and only need to be noted here for their emphasis on inclusive and transparent dialogue, with participation being the key site for discursive interaction (Forester, 1999; Healey, 1997). This theoretical position has attracted a variety of critiques in relation to the forms of participation it proposes, including that it results in precedence given to business interests (Stoker, 1997) or that diversity of social action undermines the collective basis of outcomes (Phelps and Tewdwr-Jones, 2000). Flyvbjerg (1998) and Pløger (2001) have also shown how the subtleties of 'real life politics' undo the collaborative ideal as this has tended to ignore the Foucaldian idea of power being present in every social action and that it overlooks the differentials of power in the planning process (Richardson, 1996).

The 'communicative turn' has also been criticised for being essentially prescriptive rather than explanatory (Yiftachel and Huxley, 2000), a fact supported by studies of actual participation processes that suggest that there is a tendency for certain groups to dominate and be motivated more by instrumental participation than by other rationales. As such it has been suggested that participation can be become status quo 
supporting rather than truly consensus building (Bedford et al, 2002; Campbell and Marshall, 2000; Davies, 2001; Hillier, 2003; Lowndes et al, 2001b). Such evidence provides depressing reading for those with communitarian or collaborative aspirations and appears to be linked to an emerging antagonism to the idea that enhanced procedural rights have potential for empowerment in the planning process. This appears particularly true of Campbell and Marshall's (2000) analysis of a participation exercise in the USA, from which they concluded that "Greater public involvement based on an agenda of rights has a tendency to privilege self-interest and potentially lead to the paralysis of decision-making" (page 341), leading to the warning that "Participation must avoid becoming entrapped by a rights-based agenda" (page 341). Although I acknowledge that this may articulate a widely held mistrust of the value of rights, I will suggest that such a view is inappropriate for an Anglo-Irish context, where a more social-utilitarian-orientated perception of rights predominates (Searing et al, 2003) and has led to the potential contribution of rights to planning governance being overlooked.

It will be argued here that the negative view of procedural rights is built on a number of misconceptions. The first of these is highlighted in the point made by Pløger (2001) that procedural rights do not automatically secure rights for citizens, but are only 'rights to voice' (or 'challenge', 'information', etc). That is to say that the outcomes of any rights claims ultimately depend on whether those in power accept them, so that, if enhanced rights result in short-term or parochial outcomes, it is the holders of power that are as much to blame as the actual existence of any rights. The second misconception is that rights claims will predominantly be motivated by narrow self-interest. This is true to a certain extent, in that most people become involved in the planning system only when it begins to infringe on their personal interests (Bedford et al, 2002; Rydin and Pennington, 2000) and is true of rights claims as of any other participation opportunity. However, this represents an oversimplification because it is typically based on a distorted characterisation of some stakeholders (that is, third parties) and is not strongly supported by empirical evidence. Both these misconceptions will be further examined, taking objectors to local development as an example-first by a review of the literature on objectors and then in a case study of third-party rights of appeal.

\section{Understanding the objectors}

Objectors to local development offer suitable examples through which to pursue some of these points as not only are they are commonly typified as being some of the most parochial of participants in the planning process but also, in a UK context, have a disadvantaged position in regard to procedural rights. Attempts at explaining the nature of planning disputes has a long academic pedigree, with perspectives from both political economy (Cox, 1981; Harvey, 1978) and property-right perspectives (Pearce, 1984; Webster, 1998). In the last fifteen years interest has tended to become polarised around the concepts of NIMBYs ${ }^{(1)}$ (Burningham, 2000; Freudenberg and Pastor, 1992) and environmental justice (Bullard, 1993; Morello-Frosch, 2002). In crude terms, the discourse on NIMBYs portrays oppositional activism in planning disputes as selfish parochialism and thus contrary to the public interest, whereas discourse on environmental justice sees activism in terms of collective struggles where the marginalised become empowered and thus acclaimed as being redistributive, progressive, and just. For the purposes of the paper, attention will be focused on the extensive NIMBY

(1) "Not In My Backyard", typified as the "the protectionist attitudes of, and oppositional tactics adopted by, community groups facing an unwelcome development in their neighbourhood" (Dear, 1992, page 288). 
literature from which three significant issues emerge: explanations of why individuals object to development; structural interpretations linking objectors with the wider political-social system; and the relationship between self-interest and legitimacy of protest.

\section{NIMBYs and the propensity for objection}

Dear (1992) has proposed a set of criteria that influence NIMBYism, such as the nature of the proposed development (for example, development type, size, and reputation etc) and has identified a continuum of acceptance, with schools and medical clinics being 'most welcome' and landfill and prisons being 'absolutely unwelcome'. He concluded that the single best predictor for NIMBY activity is income-with the more affluent being less tolerant of invasive development. Similarly, Cox and McCarthy (1982) found that homeownership and having children are the greatest determinants of rates of objection, but that this was not simply a function of the need to protect the monetary asset value of housing, but is a reflection of neighbourhood attachment and the desire to protect the use value of the living space. This has been elaborated by Lake (1993) who claims communities place the greatest priority on stability and constancy, which may be expressed economically (for example, protection of property rights and personal investments) and noneconomically (for example, protection of aesthetic values, social status, sanctity of the home, and the expectation of 'minimised uncertainty'). Social-psychological approaches have also suggested that it should not be assumed that objectors are driven by mercenary self-interest alone, but emphasise the perception of fear of health risks, nuisance (traffic generation, etc), distrust (of institutions and government) or a belief in the moral backing for objection (Kemp, 1990; Lee, 1989; Morrell, 1987).

This therefore suggests that, even if individuals do object to development on broadly self-interest grounds, they may not be acting just as 'possessive individualists' but may be articulating genuine and rational concerns over quality-of-life issues that they can reasonably expect the planning system to take into account. Furthermore, in such cases individuals may not be simply claiming their right of challenge, but may be acting on what they see as a civic obligation to oppose unsustainable development (Barry, 2003).

\section{Objection in a wider context}

An additional perspective has focused not on the objectors, but the on the social, economic, and cultural context of objection that creates such conflicts in the first place (Freudenberg and Pastor, 1992). It has thus been suggested that NIMBYism can be seen as a communication problem arising from political or administrative failures in the planning process (Armour, 1991; Rabe, 1994; Wolsink, 1994) or ineffectiveness in taking transaction costs into account (Brion, 1992). Lake (1993) has offered a more structural view, suggesting that the relationship between state and capital is crucial, noting that many so-called 'LULUs' (locally unwanted land uses) are needed primarily for capital, rather than society as a whole. As such, to articulate such problems in terms of NIMBYism "obfuscates the interests of capital and deflects attention away from the fundamental causes of societal problems" (page 88), which then leads to a state political-administrative response to an economic crisis that minimises the costs to capital and concentrates costs on communities. Lake thus proposes that NIMBY objections represent conflict between communities and capital or state, rather than between individuals or single communities and the wider society. Furthermore, he suggests that NIMBY objection is an inevitable component of a development process driven by commodification of land and property, so that to challenge the reasons why people object to unwelcome development is to challenge the basis of the consumption-driven development process itself. 
Kemp (1990) suggests that the level of objection in any development will also be determined partly by the level of trust in those making regulatory decisions, which focuses on the difference of perceptions between the public and the planning professionals (for example, Burgess et al, 1988; Burningham and Thrush, 2001). This is commonly portrayed as a struggle between technocracy and democracy, both from pluralist (McAvoy, 1999) and from neo-Marxist (Kemp, 1990) perspectives. The latter involves the application of Habermas's (1970) distinction between 'technical rationality' and 'practical rationality' that suggests that decisions arrived at through the objective, technical rationality of the planners will be received in terms of practical rationality of the public, who may consider it more in terms of value judgment and political choices. This points to the need for planners to understand community perspectives and suggests that a history of mistrust between public and bureaucracy may have an enduring influence on the type of practical rationality applied by an individual or community.

\section{Self-interest and the legitimacy of protest}

A final point is to note how the use of NIMBY and accusations of self-interest have been used in a derogatory way to depreciate the validity of others' arguments. Burningham (2000) has suggested that some authors (for example, Bullard, 1993) portray activism by affluent communities as selfish and illegitimate, while celebrating opposition from marginalised sections of society and then links NIMBY activity with the causes of environmental racism. This emphasises the importance of language in planning disputes, with both Kemp (1990) and Lake (1993) suggesting that the NIMBY label can be used to undermine empowerment by portraying community concerns as irrational and reactionary, thus entrenching rather than resolving conflict.

The NIMBY literature therefore contributes a number of insights to the investigation of procedural rights in planning. First, it points to a need to view rights claims in a broader context that reflects issues of culture, political power, and sociopolitical relations. Second it warns against dismissing the views of individual rights claimants as necessarily motivated by narrow self-interest or because they appear to be at odds with other concepts of the collective good or hegemonic ideas of development.

\section{Third-party rights in UK planning}

This theoretical background provides a useful way of interpreting the discourses of third-party procedural rights, particularly rights of challenge, as witnessed within the UK planning system. Although there has been a statutory requirement for participation for nearly four decades and increased enthusiasm for public involvement in the last ten years (Lowndes et al, 2001a) third-party rights of appeal have received little official consideration. It is suggested here that this is largely a result of the dominance of property interests and a particular discourse of procedural rights that misrepresents objectors, as noted in the last section.

Although third-party rights of appeal would present additional opportunities for framing citizen engagement with the planning system, Ellis (2000) argues that the case for their introduction is not primarily one of participation, but of equity. There remains a fundamental imbalance between the rights of challenge afforded to first parties (that is, developers) and those given to objectors (that is, third parties) (Corner, 1998; Hinds, 1989). Indeed, despite growing international pressure for enhanced procedural rights through agreements such as the Aarhus Convention (McCracken and Jones, 2003), third parties continue to be denied rights of participation, with most participative activity being at the discretion of the local planning authority (for example, Darke, 1999). 
Although third-party rights are currently being explored in Northern Ireland and Scotland and have been regularly recommended by reviews of the planning system (for example, Green Balance et al, 2002; RCEP, 2002; Select Committee, 2000), the government does not see a place for third-party appeals in its attempts to reinvigorate public involvement in the English planning system (DETR, 2000; DLTR, 2002). In coming to this view in its Planning Green Paper, the government has stressed three key arguments (DLTR, 2002): that third-party appeals are inconsistent with the democratically accountable system of planning (paragraph 6.20); that there is a danger of rights being dominated by frivolous appeals (paragraph 6.21); and that they would add to costs (paragraph 6.22). None of these points holds up to scrutinised analysis and they appear to reinforce the dominant discourse of administrative efficiency and reflect the private sector's view that third-party rights would have negative impacts for business (for example, Dewar, 2003; Winkley, 2002). However, Freeden's (1991) view that we should conceptualise rights as a 'protective capsule' for particularly significant attributes would suggest that attention should primarily be focused not on any unintended outcomes (for example, potential delays in decisionmaking), but on the values the rights seek to protect. As such, the absence of equal rights between developers and objectors would perhaps indicate that values of equality, communicative governance, and citizen voice are secondary to the hegemonic position of the development industry (Monbiot, 2000; Reade, 1987) and the ideology of 'full liberal ownership' of property (Honoré, 1961; Parker, 1999).

The fact that the planning green paper emphasises the dangers of frivolous appeals also suggests that the government's view of third-party rights is also based on a reification of the New Labour/communitarian ethic that there should be "no rights without responsibilities" (Giddens, 1998, page 65; see also Etzioni, 1995). Although this slogan simplifies a more complex political position, it has become an oft-repeated mantra that has seen recent expression in a range of fields of public policy (Dean and Ellis, 2002). Furthermore, when this ethic is coupled with the misconception of objectors to planning proposals and the fears that rights become primarily a channel for instrumental participation (Campbell and Marshall, 2000), one can imagine how the unequal rights status between developers and objectors can begin to be defended. However, it will be argued here that such a view is misplaced on a number of grounds. This view tends to focus attention away from the state as a holder of correlative obligations (O'Neill, 2000) towards the citizen as rights claimants and suggests that certain rights have to be deserved or have qualifying criteria rather than being inalienable and nonderogable (Cranston, 1973). This view also underestimates the strong sense of civic obligation amongst the British (Pattie et al, 2003a) and overlooks deeply held and varied views on citizenship, some of which (for example, civic republicanism) may see the challenging of political or bureaucratic decisions not as an opportunity to further self-interest, but as a duty (Barry, 2003; Kymlica and Norman, 1994).

This consideration of the dominant (that is, government) discourse on third-party rights leads to two assertions that will be tested in the case study. The first of these is that is that it is wrong to assume that any enhancement of a procedural rights regime will be used predominantly for instrumental participation, and thus contrary to the 'public interest' objectives of planning. Second is that the absence of third-party rights of challenge represents a violation of the principles of equal rights, but that this situation, although highly advantageous to certain economic interests, has been justified by government by the first assertion related to instrumental participation. It follows therefore that, if third-party rights of challenge can be shown to have relevance beyond self-interest, in principle the inequality of rights cannot be justified. 


\section{Case study: third-party rights claimants in the Republic of Ireland}

These assertions have been tested in the Irish Republic, which has had third-party rights of appeal since the establishment of the comprehensive planning system in 1963. This right is now used by many as a primary mechanism for engaging with planning (Ellis, 2002) and, subject to a few qualifying criteria, anyone can challenge any development control decision made by a local planning authority, by making an appeal to a central planning board (An Bord Pleanála). Although the board has powers to dismiss any vexatious or frivolous appeals, it determines in excess of 4500 appeals a year of which nearly $50 \%$ come from third parties $-40 \%$ of which result in a complete refusal of planning permission and most others with revised conditions.

The Irish case offers the opportunity to develop an understanding of third-party rights of challenge by identifying the types of social discourse used by rights claimants. The term 'discourse' is used here to refer to ways of seeing something, a set of views and attitudes on a particular topic, with 'social discourse' referring to perceptions that are shared by a group of people (Barry and Proops, 2000). The use of discourse analysis can open up a deeper understanding of planning concepts and can be extremely effective in questioning the things we take for granted (Hastings, 1999; Richardson, 2002). In this research I aimed to uncover the attitudes of rights claimants and in particular their perceptions of issues such as the public interest, property rights, and citizenship. In order to identify these discourses, a technique known as Q-methodology was used (see Addams, 2000; Brown et al, 1999; McKeown and Thomas, 1988) which provides a number of advantages over more traditional survey-based techniques, particularly in terms of minimising the influence of the researcher, allowing the subjects "to speak for themselves" (Dryzek and Berejikan, 1993), while not requiring large numbers of participants in order to produce valid results (Addams, 2000).

For the purpose of the case study, the methodology consisted of identifying an initial 104 statements representing the whole range of attitudes on the issues of interest. These were sourced primarily from people who had made third-party planning appeals in the Irish Republic and collected through telephone interviews and survey returns from a previous research project (Ellis, 2002). With a cell structure similar to that used by Dryzek and Berejikan (1993), thirty six of the statements (shown in table 1, over) were then selected to ensure an adequate representation of four main areas of concern: planning and third-party appeals; concepts of rights and citizenship; concepts of community and public interest; and environment and development. A sample of thirty-five individuals who had recently made a third-party appeal was then selected from the website of An Bord Pleanála to reflect the broad profile both of appellants and of the type of development appealed against (mostly domestic development). The participants were contacted after they had lodged an appeal, but before they knew its outcome, so that the attitudes primarily reflect the motivations for making an appeal, not its success or failure. These appellants then ranked each of the thirty-six statements according to their importance on a nine-point scale ranging from +4 (strongly agree) to -4 (strongly disagree). Preference between the statements was 'forced' by controlling the number of statements that could be given each score according to a normal distribution, so that the -4 and +4 ranking could only be allocated two statements each, -3 or +3 three statements each, and so on, with the neutral ranking having eight statements. The participants' returns were then collectively analysed using the PQMethod software (http://www.rz.unibw-muenchen.de/ p41bsmk/qmethod/), which uses principal components analysis and varimax to generate five idealised discourses, as shown in table 1. Although a relatively small number of participants, this still provides a statistically relevant profile of appellants' attitudes as, unlike standard survey analysis, Q-methodology establishes patterns within and across individuals rather than across 
Table 1. Statement rankings with scores for each discourse.

Statement

Factors

('idealised discourses')

A $\quad$ B $\quad$ C $\quad$ D $\quad$ E

1 If planning was fair and concerned with the public interest, there would not be a need for third-party appeals.

2 Our duties towards the environment should come before our rights to property.

3 There is a need for mediation between the objector and the developer.

4 If you are linked to a local official or politician, it can affect the way a planning application is considered.

5 Greenpeace and other eco-warriors are just extremists.

6 Property development has no benefit to the community.

7 Enforcing your rights is difficult for those on limited incomes.

8 Appeals would be unnecessary if planners were well qualified with sufficient resources.

9 Penalties should be imposed for abuse of the appeals system.

10 We face a major global environmental catastrophe.

11 The public interest is defined by economic needs.

12 You can't just think about the development next dooras all development affects the global environment.

13 The planning system is biased in favour of professionals who understand the jargon.

14 The quality of my local area is very important to me and I'll put up a good fight to make sure its not spoiled.

15 The cause of the ecological crisis is greed and money.

16 The planning system should protect a homeowner's investment.

17 Third-party appeals are the only way the public can influence planning.

18 The planning authority had not fully considered the implications of the proposed development and should listen more to those with local knowledge.

19 People should take things into their own hands and not rely on the government to make the best decision.

20 Councillors are democratically elected-let them make the difficult decisions.

21 My neighbours see things in a different way than I do.

22 Third-party party appeals are in the general interest, as they are not motivated by profit.

23 Environmental organisations like Friends of the Earth fight $\begin{array}{lllll}1 & -1 & -2 & 0 & -2\end{array}$ for all our rights.

24 It is your duty to make an appeal against poor development if you want to make Ireland a better place for your children.

25 If someone has a legal right, they should exercise that right $-2 \quad \begin{array}{lllll}0 & -4 & -4 & 1\end{array}$ or have it taken away.

26 Privacy is very important to me. $\quad \begin{array}{lllll}0 & 0 & 2 & 4 & 0\end{array}$

27 Town planners tend to be scruffy, unprofessional individuals $-3 \quad \begin{array}{lllll}-2 & 1 & -4 & -1\end{array}$ who know more about rules and regulations than they do about common sense.

28 Appeals should only be made by people who are local and totally identifiable.

29 The environment is better now than it was 100 years ago.

$\begin{array}{rrrrr}-3 & 1 & -2 & 4 & 2 \\ 0 & -4 & -2 & -3 & 4\end{array}$


Table 1 (continued).

Statement

Factors

('idealised discourses')

\begin{tabular}{|c|c|c|c|c|c|c|}
\hline & & \\
\hline & & A & B & $\mathrm{C}$ & $\mathrm{D}$ & $\mathrm{E}$ \\
\hline 30 & $\begin{array}{l}\text { We need to tackle local environmental problems such as } \\
\text { litter, dog mess, and vandalism before saving the world. }\end{array}$ & -1 & 0 & 2 & -3 & -3 \\
\hline 31 & $\begin{array}{l}\text { Third parties' costs should be reimbursed if they are } \\
\text { successful. }\end{array}$ & 0 & 3 & -1 & -3 & -1 \\
\hline 32 & $\begin{array}{l}\text { I do not normally object to development, but sometimes } \\
\text { it goes over the top. }\end{array}$ & 2 & 1 & 3 & -1 & 0 \\
\hline 33 & $\begin{array}{l}\text { Third-party appeals are a way of securing the proper } \\
\text { planning and development of an area. }\end{array}$ & 2 & 4 & 0 & 1 & -1 \\
\hline 34 & Property development is the future. & -4 & -2 & 0 & -1 & -3 \\
\hline 35 & $\begin{array}{l}\text { People who make third-party appeals are powerless against } \\
\text { a pro-development planning system. }\end{array}$ & -1 & -3 & -1 & 1 & 0 \\
\hline 36 & $\begin{array}{l}\text { I'm interested in protecting my house and job not crappy } \\
\text { issues like human rights. }\end{array}$ & -4 & -1 & -3 & 0 & 0 \\
\hline \multicolumn{2}{|c|}{ Percentage variance explained } & 19 & 14 & 13 & 10 & 7 \\
\hline
\end{tabular}

traits such as gender and age, and operates on the assumption of 'finite diversity' in that there are generally not as many discourses as there are participants (Barry and Proops, 2000). Each of the five discourses were subject to further interpretation by using detailed notes from interviews. Their distinctive characteristics were identified and each was given a label in an attempt to portray its overall features. It is important to note that it is not claimed that the discourses are necessarily representative of all third-party appeals in the Republic of Ireland but they are essentially heuristic, providing an initial insight into the attitudes of such rights claimants.

Each discourse is described below, with the numbers in parentheses referring to the statements with rankings of significance to the point under discussion.

\section{Discourse A-the critical green}

The distinctive features of this discourse are its strong disagreement with the primacy of property rights and low opinion of the benefits of development, coupled with firm environmental beliefs. It is sceptical about the probity of the local planning process and sees third-party appeals as a way of asserting collective values. Of all discourses, it also explains the greatest variation in all the responses generated from the survey.

The discourse strongly rejects the notion that property development offers the potential for societal improvement (34) and believes that duties to the environment should come before property rights (2). It thus sees the environment as having a moral dimension and recognises the value of political activism in environmental issues $(5,23)$. It sees the environment, not as a local amenity issue, but as part of the broader ecosystem $(30,12)$. It mistrusts the judgment of local councillors (20) and supports the idea of planning $(33,27)$, recognising its value for broader environmental protection (16) with third-party appeals a way of asserting the public interest $(33,22)$. It strongly believes that the planning process should benefit from local knowledge (18), but, whereas other discourses may base such a view on taking power away from the local council (and perhaps to themselves), it is suggested that discourse A does so out of recognition of the broader benefits and ethic of participation (that is, giving power to the public).

In terms of citizenship, the discourse strongly asserts the value of human rights (36), recognising how some sections of society are unable to realise them fully (7) and 
sees the giving of rights as part of a social contract that should be reflected in citizen responsibilities $(2,24)$. The discourse displays some reluctance in making an appeal (32) and would rather have the option of objecting anonymously.

\section{Discourse B-the public interest guardian}

This discourse is primarily distinguished by its close identification with public interest issues and a faith in the use of appeals to secure better communitarian outcomes.

The discourse firmly believes that third-party appeals improve the decisionmaking process (33) and they can make a real difference (35), to the point that other forms of activism may not be needed $(19,17)$. As such, it firmly defends the right to make an appeal $(25,1)$ and believes that any appeal costs should be reimbursed if successful $(31)$. It does not, however, identify with notions of duty $(2,24)$. In defending the public interest, the discourse believes that it expresses the view of the local community (21) and takes this as a strong mandate to fight the case $(14,32)$. Unlike most other discourses, it agrees with the need for mediation between objector and developer, in the recognition that this may be an appropriate way to resolve differences for the common good. It is neutral on issues of privacy (26) and property rights (2). It has more faith in the probity of the planning system than discourses C and D (4), but still does not have much trust in local politicians, while being neutral on political activism $(19,5,23)$ and other ways of influencing the planning system.

It believes that environmental quality is declining (29) but has a fairly parochial view of such issues $(12,14,30)$ strongly rejecting alarmist views (10) and neutral on the value of environmental nongovernmental organisations (NGOs) $(5,23)$.

\section{Discourse $\mathrm{C}$ - the prodevelopment conservative}

The distinguishing features of this discourse include its parochial and conservative outlook, a poor opinion of the local planning process and strong support for property rights and development.

Of all the discourses identified, this tends to display more stereotypical NIMBY attitudes than the others - it believes that that property rights should be elevated above environmental issues (2) and that property development can bring wide benefits to the community (6), but is determined that its property and the local area should not be effected by it. Like several of the other discourses, it has little faith in the democratic process of planning decisions $(4,20)$ and sees the use of third-party rights of appeal as a way of by-passing the local polity to achieve 'proper' planning of an area (33). It would like to retain a right to object irrespective of the quality of the decisionmaking process (1). Although there is a poor view of local councillors, there appears to be support for planning officers (27) and the whole idea of planning is given mild support on condition that it facilitates development and protects the local neighbourhood $(16,18)$. While accepting development can bring benefits, it is relatively neutral on environmental issues, making little connection between this and the use of third-party appeals $(2,12)$. The discourse places an importance on both the monetary and use value of the home $(26,16)$.

The discourse recognises the limitations of a rights-based system (7), but believes this is an essential mechanism for expressing concerns and fighting for individual interests $(1,14)$, while being against direct-action forms of activism $(23,5)$. The discourse expresses a strong sense of duty (24) or at least the concept of duty is invoked (consciously or subconsciously) to cover strong financial motivations (16). Although suggesting that neighbours may hold similar views, it does not wish to be seen as being unreasonable in its objections (32) and would like to retain the right to launch covert objections (28). 


\section{Discourse D-the individual proceduralist}

The distinctive features of this discourse are the high value placed on privacy, a procedural outlook, and a faith in administrative authority and technology.

Above all else, this discourse places very different values on privacy than other discourses (26), appearing to reflect the importance placed on the home, particularly in terms of its asset value (16). This also underlies an individualist outlook, with little interest in issues related to the public interest $(1,22,33)$ and no sense of citizen duties $(2,24)$. This individualist outlook is also reflected in the fact that it sees little justification for the need to reimburse successful appellants (31) and is neutral on community issues (21). Another key feature is a sense of procedural propriety - it strongly agrees that there should be fines for any abuse of the planning system (9) and a need for openness when making appeals (28). This suggests that the discourse is confident and unashamed of the reasons for making an appeal (32), despite being primarily motivated by self-interest (16). It seeks to reserve the right of appeal under any circumstances $(25,2)$. Like other discourses, it is suspicious of paternalism in the planning system, but does show faith in professionalism of planners (27) and of all the discourses, is least dismissive of local councillors (20). This may suggest a faith in administrative authority and the state, as it is dismissive of political activism (19, 23), but still mildly defeatist about what can be gained from making an appeal $(33,17)$. The discourse recognises deteriorating environmental quality $(29,15)$, seeing this as having relevance beyond the immediate area (30).

This discourse shuns the value-laden world of politics, being neutral on statements related to the broader issues of human rights $(23,36)$ and probably sees the appeal process as an extension of the bureaucratic process, rather than as a citizen right.

\section{Discourse $\mathbf{E}$ - the antidevelopment process sheriff}

The distinguishing features of this discourse are its strong belief that third-party appeals should be used to correct process failures in the planning system and a low opinion of the benefits of property development.

The discourse sees the planning system as being generally open and fair $(13,19)$, but prone to occasional policy failures, which third-party appeals can be used to correct (1). Although not casting doubt on the probity of the local process (4), it has little trust in councillors (20). It is also different from the other discourses in that it sees the planning system as being fairer than that expressed in all but discourse A, having more faith in the planning profession $(8,13)$, with the causes of policy failure being underresourcing rather than corruption or incompetence $(8,27)$.

The discourse sees the environmental lobby as being partisan (23) and alarmist $(10,29)$, perhaps reflecting an underlying mistrust in pressure group politics. It places a very high value on the need for openness when making appeals (28), but is distinctive in its strong rejection of the need for penalties for abuse of the system (9). It does not see appeals as a way of securing the proper planning of an area (33), as this should be determined by a much broader range of issues (17). In viewing planning primarily as a technical activity, it does not have a strong view of rights issues $(36,23)$ and, unlike every other discourse, does not see low income as being an impediment to the realisation of rights (7). This is part of a broader cynical outlook that rejects any notion of idealism $(5,23)$ and firmly believes (and accepts) that the world is primarily motivated by money and self-interest $(15,22)$.

The discourse appears to hold complex views on the environment, agreeing strongly that the environment is better now than a century ago (29), is neutral on whether we are facing an ecological catastrophe (10), but sees money and greed as eroding environmental quality (15) and distrusts the activities of some NGOs (5). 
It believes its views are not widely shared by its neighbours (21), yet is prepared to be quite open about making an appeal $(28,32)$.

Before moving on to relate this analysis to the understanding of procedural rights, it is worth highlighting areas of consensus between these discourses. For example, all but discourse D appear comforted by statement 24 , which links making an appeal with the welfare of future generations, and statement 32 that suggests that, in making an appeal, appellants are not being overly sensitive or apt to complain (Edwards and Potter, 1992; noted in Burningham, 1998, page 550). Also of significance is that all discourses express varying levels of distrust in local councillors (20) and cast doubt on the probity of the local planning process (4), despite all but discourse $C$ supporting planners themselves (27). Somewhat surprisingly, every discourse shows relative ambivalence in terms of statement 17, which highlights the importance of third-party appeals to the broader planning system. This may suggest either that appellants see appeals as only part of a broader strategy for influencing the system or that they ultimately do not have that much faith in the effectiveness of the appeal process.

\section{Towards an understanding of third-party rights in planning}

These discourses of objection contribute a number of insights into the understanding of third-party rights in planning, as follows.

\section{The complexity of motivations}

First, the case study strongly supports the conclusion of much of the literature on NIMBYism that it is misguided to reject the views of objectors simply as being parochial, self-interested protectionism. Admittedly, some of these discourses (particularly discourse C) reflect some of the characteristics one would tend to associate with a stereotypical NIMBY, but the majority do not and instead portray a range of motivations, that includes cynicism (discourse E), due process (discourse D), and environmentally inspired altruism (discourse A). Even where there are NIMBY undertones, the overall discourse reveals a more complex motivation for objection than just opposition to a particular development. These all represent an expression of self-interest in some form, but it is clearly wrong to accept that they are acting out some simple form of instrumental participation as proposed by Campbell and Marshall (2000). Indeed, we cannot be naive enough to believe that, given the high societal value on individual interest, everyone would automatically subsume their own concerns into those of the collective will and one would expect individuals to articulate their own points of view given the opportunity of consultation - this is precisely the point of participation. It is a curious position that allows businesses and corporations shamelessly to project their narrow interest, yet castigates individual citizens for doing the same thing. A rights approach may indeed encourage more individual engagement with the planning system, but it would be wrong to dismiss the views expressed in this way as being 'unrepresentative', particularly given the difficulties for individual objectors to know how many others share their views or whether they have weight of numbers (Bedford et al, 2002). Furthermore, Sanderson (1999) notes that accusations of unrepresentativeness are commonly used by professionals to dismiss critical voices and protect the status quo.

Therefore the assumption that appellants will inevitably pursue narrow NIMBY objectives through rights claims is clearly an oversimplification and depreciates the panoply of motivations of most appellants while frustrating the objective of a fully inclusive planning process. This is particularly true if one considers that this analysis has investigated only individual appellants and not touched on the roles businesses, civic societies, government agencies, and environmental groups may play in lodging 
third-party appeals. It is therefore questionable that enhanced third-party rights of challenge would be predominantly used frivolously and against collective interests.

\section{The importance of context}

The discourses of objection also highlight the importance of context to understanding the value and motivations for invoking procedural rights. This point relates to the broader value of an institutionalist approach that allows the interaction between the structural forces in society and the fine-grain practices and discourses of governance (Ellis, 2001a; Healey, 2003). An appreciation of the social-structural construction of objection not only helps us understand the concerns that spark rights claims, but also suggests why certain groups may invoke procedural rights more than others (for example, higher income groups, the retired) or why they should focus on certain types of development, such as telecommunication masts. Such a perspective also underlines the importance of viewing stakeholders in the planning process as socially embedded people, rather than abstractions (Healey and Gilroy, 1990; Lo Piccolo and Thomas, 2001).

Just as Searing et al (2003) have shown how different political traditions affect attitudes to citizenship and rights in the United Kingdom and the United States, the discourses of rights claimants can be expected to reflect the specific context that frames individual actions. For example, in a close-knit rural community, neighbours are less likely to invoke rights against one another and may even have recourse to more informal conflict-resolution mechanisms (Parker, 1999). Compare this with a more individualized, anonymous urban context, where rights claims may be the only means of resolving conflict. Indeed, analysis of the geographic distribution of third-party appeals in the Irish Republic suggests that planning applications in Dublin are four times more likely to be subject to third-party appeal than those in rural areas (Ellis, 2001b).

A further example of the influence of context is that most of the identified discourses display a deep mistrust of the probity of the local planning system, particularly of the role of local councillors. This has wide acceptability in the Republic of Ireland, where planning and other government functions have been embroiled in corruption for decades. In recent years this issue has rarely been out of the media, because of the high-profile Flood Tribunal, which was established in 1997 to investigate such corruption and has so far exposed the illicit practices of a number of high-profile individuals, including councillors, planners, and even a cabinet minister (Cullen, 2002). This highlighted the potential for corruption in the Irish planning system and, although current practices have been vastly improved, it has left the public with deep-rooted misgivings about the probity of the planning system and a questioning of the legitimacy of politico-rational policy decisions (Healey, 1990). When this is coupled with the fact that the opportunities for predecision participation are significantly reduced in the Irish Republic compared with the United Kingdom (Ellis, 2002), it does not come as much of a surprise that people feel motivated to seek individual or group justice through the third-party appeal system. It is one thing to champion representative democracy above rights claims, but, if there is little trust in politicians, this may not be an accepted channel of accountability. This may also apply to the United Kingdom, where trust in politicians is now extremely low and where people are far more likely to trust nonpolitical state institutions such as the courts (Pattie et al, 2003b). In this respect, Darke (1999) has provided evidence that enhanced participatory rights increase the public's trust in the system and make them more likely to accept the ultimate outcome of the process. 


\section{Fairness in process}

This last point relates to the unease expressed by both Hillier (2003) and Campbell and Marshall (2000) that rights given to third parties enable them, in some circumstances, to dominate participation processes to the detriment of both the public interest and the role of the professional planner. Indeed, it is implied that, if participants cannot be trusted to pursue public interest values, then the responsibility should be more firmly transferred to planners and elected representatives. However, the discourses identified above confirm the view of Kemp (1990) that conflicts between decisionmakers and objectors are often frustrated by differences in values expressed in the technical rationality of planners and the practical rationality of the objectors, so that a consensus over what constitutes the public interest is often elusive. This issue brings into focus a debate over power relations between planners and 'the planned' as an obstacle to communicative governance (Healey, 2003; Pløger, 2001). In the absence of adequate rights of challenge, technical rationality will invariably dominate the policy processes in planning to the further frustration of those unhappy with the development trajectory of an area. There are plenty of examples from the Republic of Ireland (for example, Allen and Jones, 1990) that confirm that technocratic decisions are not always the most appropriate (Dryzek, 1990). This supports Healey's (1997) suggestion of why rights of challenge are an important way of promoting collaborative inclusionary planning, particularly in a situation like that of the United Kingdom, where such rights are available to the promoters of development, but not to objectors. Therefore, if we want the planning profession to be a more strident advocate for the public interest, it must protect the legitimacy of any decision by ensuring fairness in process, of which equal rights are a precondition.

This section therefore confirms the assertion made earlier that it is wrong to assume that third-party rights of appeal would inevitably be used 'without responsibility' and, in such a situation, the unequal rights status of objectors and developers should not be sustained. It follows, therefore, that the debate on the potential introduction of third-party appeals in the United Kingdom needs to be evidence based and better informed by matters of principle. It is these matters of principle that ultimately make the issue so contentious, particularly as third-party rights challenge deeply held ideologies of private property rights and citizen power. Above all, we need to move away from simplistic notions of NIMBYism or self-interest as being inherently bad and begin to explore how every citizen can be given the capacity to channel his or her views into decisionmaking.

\section{Conclusion}

The analysis presented here helps clarify the role of rights in planning and, by implication, provides a number of insights into the nature of participation that support Campbell and Marshall's (2000, page 339) view that we need a more sophisticated approach to thinking about public involvement in planning practice. This appears to be particularly true in developing an understanding of rights in planning, which should reflect the complex context from which rights claims emerge and recognise their connection to deeper held views of citizenship. This broad conclusion has implications for understanding the rationales for participation and suggests that the five-fold model offered by Campbell and Marshall (2000) has some value as a heuristic tool, but is unable to cope with the complex social, cultural, and political worlds in which the decision to invoke procedural rights are made.

The discourses of objection presented here also suggest that the resistance to thirdparty rights of appeal in the United Kingdom is not evidence based and does not reflect any appreciation of what rights may mean in the planning context. It cannot 
be ignored that, although rights are problematic as a contested concept, they generally represent a valuable and accepted mechanism for safeguarding fundamental attributes of liberal democracies. A key difficulty, however, is that, within planning, rights discourses tend to have emphasised rights as vehicles for expressing interests, rather than emphasising the values that they seek to protect. As a result, the invoking of rights becomes seen as a problem of how to manage competing interests in the context of other models of accountability (for example, representative democracy), while obfuscating the fact that development interests are accorded the protection of rights and third parties are not. This paper introduced Freeden's (1991) view that rights should be regarded as 'protective capsules' for key values, which taken to its logical conclusion would suggest that the refutation of third-party rights of challenge represents as much a rejection of the principles of equality and participatory governance as the mechanism of rights itself. Although it is not proposed that the rights agenda offers a panacea to the governance difficulties faced by the planning system, it is suggested that rights may have some potential for clarifying, protecting, and prioritising the most important values that we wish to see reflected in the planning system. In any case, rights do not deserve the reputation accorded to them by some commentators. Conferring rights on values, such as participation or environmental sustainability, would provide a strong symbolic signal of what the planning system should ultimately seek to achieve and as part of the institutional framework would shape the actions of citizens, developers, and planners accordingly.

This does not, however, escape the significant management challenges that an enhanced rights regime would present, which would demand new skills and procedures for balancing and evaluating the range of stakeholder interests. Although this remains a fundamental unknown and has not been a prime focus of this paper, it must be acknowledged. The scale of such a challenge would ultimately rest on the type of rights regime introduced and would have to take into account fears that rights inevitably result in paralysis in decisionmaking (Campbell and Marshall, 2000). Such a view is not, however, consistent with the experience of all those countries that do have more robust rights regimes than the United Kingdom [for example, the Republic of Ireland or New Zealand (see Green Balance et al, 2002)]. Indeed to focus on the unintended consequences of enhanced rights misses the point that it should be the encapsulated values that should be the prima facie issue when debating the worth of rights.

One additional area in which enhanced rights may challenge current planning practice is through a further questioning of the dominant notion of a unitary public interest. This implies that the utility of a proposed action can somehow be aggregated irrespective of the distribution of costs and benefits, whereas a rights approach would suggest that there has to be some formal consideration of who bears the costs and, depending on the rights regime, whether these result in substantive and/or procedural impacts that exceed acceptable limits. An enhanced rights regime may therefore stimulate a broader questioning of how we evaluate the outcomes of planning practice. The discourses of objection discussed earlier in the paper also point to the difficulties in defining the public interest in that it suggests that, under the present pattern of social relations, the invoking of such rights may bear little relationship to a consensus-derived public interest, rather than the inherently conflictual vision of societies promoted by more leftist perspectives. This is valuable in that it not only reveals the real tensions experienced by participants in the planning process, but also contributes to the understanding of why and how power is actually used in planning, rather than how we would normatively wish to see it being used (Friedmann, 1998, Yiftachel and Huxley, 2000).

It has also been argued that the 'official' discourse on third-party rights appears to be based on an inappropriate caricature of development objectors which, when 
combined with dominant communitarian notion of citizenship, justifies the imbalance of rights between objector and developer. The discourses of objection presented above suggest that the dominant view that third-party appellants simply act out of narrow selfinterest oversimplifies the situation to the point of distortion and ignores the complex contexts in which they act. It has also overlooked the fact that objectors are not just NIMBYs but, indeed, citizens and thus informed by competing notions of citizenship. Furthermore, this research suggests that, even if citizens use rights claims to protect parochial self-interests, the lack of collectivity should not be blamed on the existence of rights per se but a deeper study should be made of the factors that frame individual actions and governance activity. This therefore suggests that, to understand discourses of objection, one needs to appreciate not only the dominant consumption-driven ethos of society but also the differing rationalities and levels of trust between planning professionals and the public. Indeed, as noted by Dryzek (1990) and Sanderson (1999), rights of challenge may actually have a place in bringing about a long-term transition towards 'communicative rationality' by forcing agencies into dialogue and understanding with the public.

Acknowledgements. Many thanks to Richard Cowell, Una Hand, John Barry, and the anonymous referee who provided detailed guidance on an early draft.

\section{References}

Addams H, 2000, “Q-methodology”, in Social Discourse and Environmental Policy Eds H Addams, J Proops (Edward Elgar, Cheltenham, Glos) pp 14-40

Alexander E R, 2002a, "Planning rights: towards normative criteria for evaluating plans" International Planning Studies $7191-212$

Alexander E R, 2002b, “The public interest in planning: from legitimation to substantive planevaluation" Planning Theory $1226-249$

Allen R, Jones T, 1990 Guests of the Nation: The People of Ireland Versus the Multinationals (Earthscan, London)

Armour A A, 1991, "The siting of locally unwanted land uses: towards a cooperative approach" Progress in Planning $351-74$

Barry J, 2003, "Resistance is fertile: cultivating the virtues of sustainability citizenship", unpublished paper, Institute of Governance, Queen's University of Belfast, Belfast

Barry J, Proops J, 2000 Citizenship, Sustainability and Environmental Research (Edward Elgar, Cheltenham, Glos)

Bedford T, Clark J, Harrison C, 2002, "Limits to new public participation practices in local land use planning” Town Planning Review 73311 - 331

Benton T, 1993 Natural Relations: Ecology, Animal Rights and Social Justice (Verso, London)

Berke P R, Erickson N, Crawford, J, Dixon J, 2002, "Planning and indigenous people: human rights and environmental protection in New Zealand" Journal of Planning Education and Research $22115-143$

Boyle A, Anderson M (Eds), 1996 Human Rights Approaches to Environmental Protection (Clarendon Press, Oxford)

Brion D J, 1992, "An essay on LULU, NIMBY and the problem of distributive justice" Environmental Affairs $15437-503$

Brown S, Durning D W, Selden S, 1999, "Q-methodology”, in Handbook of Research Methods in Public Administration Eds G J Miller, M L Whicker (Marcel Dekker, New York) pp 599-638

Buergenthal T, 1997, "The normative and institutional evolution of international human rights" Human Rights Quarterly $19703-723$

Bullard J (Ed.), 1993 Confronting Environmental Racism: Voices from the Grassroots (South End Press, Boston, MA)

Burgess J, Limb M, Harrison C M, 1988, "Exploring environmental values through the medium of small groups: 1. Theory and practice" Environment and Planning A 20 309-326

Burningham K, 1998, "A noisy road or noisy resident? A demonstration of the utility of social constructionism for analysing environmental problems" Sociological Review 46536 - 563

Burningham K, 2000, "Using the language of NIMBY: a topic for research, not an activity for researchers" Local Environment 5(1) 55-67 
Burningham K, Thrush D, 2001, “'Rainforests are a long way from here': the environmental concerns of disadvantaged groups", Joseph Rowntree Foundation, York

Campbell H, Marshall R, 2000, "Public involvement in planning: looking beyond the one to the many" International Planning Studies 5321 - 344

Campbell H, Marshall R, 2002, "Utilitarianism's bad breath? A re-evaluation of the public interest justification for planning" Planning Theory $1163-187$

Corkindale J, 1999, "Land development in the United Kingdom: private property rights and public policy objectives" Environment and Planning A 312053 - 2070

Corner T, 1998, "Planning, environment and the ECHR" Journal of Planning and Environmental Law April, $301-314$

Cox K R, 1981, "Capitalism and conflict around the communal living place", in Urbanisation and Urban Planning in Capitalist Societies Eds M J Dear, A J Scott (Methuen, New York) pp $431-455$

Cox K R, McCarthy J J, 1982, "Neighbourhood activism as a politics of turf: a critical analysis", in Conflict, Politics and the Urban Scene Eds K R Cox, R J Johnston (Longman, Harlow, Essex) pp 199-219

Cranston M, 1973 What are Human Rights? (Bodley Head, London)

Crow S, 2001, "What price a room with a view? Public interest, private interests and the Human Rights Act" Journal of Planning and Environmental Law December, 1349 - 1359

Cullen P, 2002 With a Little Help From My Friends: Planning Corruption in Ireland (Gill and Macmillan, Dublin)

Darke R, 1999, "Public speaking rights in local authority planning committees" Planning Practice and Research 14(2) $171-183$

Davies A R, 2001, "Hidden or hiding? Public perceptions of participation in the planning system" Town Planning Review $72193-216$

Dean H, Ellis K, 2002, "Dependency, responsibility and rights", end of award report, ESRC award no. 000239425, http://www.regard.ac.uk/research_findings/R000239425/report.pdf

Dear M, 1992, "Understanding and overcoming the NIMBY syndrome" Journal of the American Planning Association $\mathbf{5 8} 288$ - 300

DETR, 2000, "Response to the CM 4891", Department of Environment, Transport, and the Regions (The Stationery Office, London)

Dewar D, 2003, "Scots take progressive lead" Planning 4 April, page 8

DLTR, 2002, "Planning green paper-planning: delivering a fundamental change", Department of Local Government, Transport and the Regions (The Stationery Office, London)

Dryzek J S, 1990 Discursive Democracy: Politics, Policy and Political Science (Cambridge University Press, Cambridge)

Dryzek J S, Berejikan J, 1993, "Reconstructive democratic theory" American Political Science Review 8(1) $48-60$

Dworkin R, 1984, "Rights as trumps", in Theories of Rights Ed. J Waldron (Oxford University Press, Oxford) pp $153-167$

Eckersley R, 1996, "Greening liberal democracy", in Democracy and Green Political Thought Eds B Doherty, M de Geus (Routledge, London) pp 212 - 236

Edwards D, Potter J, 1992 Discursive Psychology (Sage, London)

Ellis G, 2001a, "The difference context makes: planning and ethnic minorities in Northern Ireland" European Planning Studies 9339 - 358

Ellis G, 2001b, "The implications of third party planning appeals for Northern Ireland", School of Environment Planning, Queen's University, Belfast

Ellis G, 2002, "Third party rights of appeal in planning: reflecting on the experience of the Republic of Ireland" Town Planning Review 73 437-466

Ellis H, 2000, "Planning and public empowerment: third party rights in development control" Planning Theory and Practice 2 203-217

Etzioni A, 1995 The Spirit of Community: Rights, Responsibilities and the Communitarian Agenda (HarperCollins, London)

Fagence M, 1977 Citizen Participation in Planning (Pergamon, Oxford)

Finlay J, Bird S, 2002, "Alconbury a year on: Article 6 challengers face stiff uphill struggle after Court of Appeal Begum and Adlard adopts a schematic approach?" Journal of Planning and Environmental Law September, 1045 - 1050

Flyvbjerg B, 1998 Rationality and Power (Chicago Univeristy Press, Chicago, IL)

Forester J, 1999 The Deliberative Practitioner (MIT Press, Cambridge, MA)

Freeden M, 1991 Rights (Open University Press, Milton Keynes, Bucks) 
Freudenberg W, Pastor S, 1992, "NIMBYs and LULUs: stalking the syndromes" Journal of Social Science 48(4) 39-61

Friedmann J, 1998, "Planning theory revisited" European Planning Studies 6245 -253

Giddens A, 1998 The Third Way - The Renewal of Social Democracy (Polity Press, Cambridge)

Goodin R E, 1985 Protecting the Vulnerable (University of Chicago Press, Chicago, IL)

Grant M, 2000, "Human rights and due process in planning" Journal of Planning and Environmental Law December, 1215 - 1225

Green Balance, Leigh Day \& Co., Popham J, Purdue M, 2002, "Third party rights of appeal in planning", produced for Campaign to Protect Rural England, Civic Trust, Environmental Law Foundation, Friends of the Earth, ROOM (National Council for Housing and Planning), Royal Society for the Protection of Birds, Town and Country Planning Association, World Wide Fund for Nature-UK; copy available from CPRE, 25 Buckingham Palace Road, London SW1 0PP

Habermas J, 1970, "Towards a theory of communicative competence", in Patterns of Communicative Behaviour Ed. H P Dreitzel (Macmillan, New York) pp 114 - 150

Hague $\mathrm{C}$ et al, 2003, "Participatory planning for sustainable communities: international experience in mediation, negotiation and engagement in making plans", London Office of the Deputy Prime Minister, http://www.odpm.gov.uk/stellent/groups/odpm_planning/documents/pdf/ odpm_plan_pdf_023784.pdf

Hancock J, 2003 Environmental Human Rights (Ashgate, Aldershot, Hants)

Harrison M L, 1987, "Property rights, philosophies and the justification of planning control", in Planning Control, Philosophies, Prospects and Practice Ed. M L Harrison (Croom Helm, London) pp $32-58$

Hart D, 2000, "The impact of the European Convention on Human Rights on planning and environmental law" Journal of Planning and Environmental Law February, 117 - 133

Harvey D, 1978, "Labor, capital and class struggle around the built environment in advanced capitalist societies", in Urbanization and Conflict in Market Societies Ed. K Cox (Methuen, London) pp 9-37

Harvey D, 2000 Spaces of Hope (Edinburgh University Press, Edinburgh)

Hastings A, 1999, "Discourse and urban change: introduction to the special issue" Urban Studies $367-12$

Hayward T, 2000, "Constitutional environmental rights: a case for political analysis" Political Studies $\mathbf{4 8} 558-572$

Healey P, 1990, “ Policy processes in planning” Policy and Politics 1891 - 103

Healey P, 1997 Collaborative Planning: Shaping Places in Fragmented Societies (Macmillan, London)

Healey P, 2003, "Collaborative planning in perspective" Planning Theory 2(2) $101-124$

Healey P, Gilroy R, 1990, “Towards a people-sensitive planning?” Planning Practice and Research 5(2) $21-29$

Herling D, Purdue M, 2000, "The divide between procedural and substantive unfairness" Journal of Planning and Environmental Law July, 666 - 677

Hillier J, 2003, "Puppets of populism?" International Planning Studies 8157 - 166

Hinds W, 1989, "Third party objections to planning applications: an expectation of fairness" Journal of Planning and Environmental Law November, 742-748

Honoré A M, 1961, “Ownership", in Oxford Essays in Jurisprudence Ed. A G Guest (Oxford University Press, Oxford) pp $107-147$

Howe E, 1994 Acting on Ethics in City Planning (CUPR Press, Brunswick, NJ)

Human Rights Act, 1998 Public General Acts - Elizabeth II chapter 42 (The Stationery Office, London)

Imrie R, 1996, "Equity, social justice and planning for access and disabled people" International Planning Studies 1(1) 17 - 34

Kemp R, 1990, "Why not in my backyard? A radical interpretation of public opposition to the deep disposal of radioactive waste in the United Kingdom" Environment and Planning $A \mathbf{2 2}$ $1239-1258$

Krueckeberg D A, 1995, "The difficult character of property: to whom do things belong?" Journal of the American Planning Association 61301 - 309

Kymlica W, Norman W, 1994, "Return of the citizen: recent work on citizenship theory" Ethics 104(1) $352-381$

Lai L W C, 1997, "Property rights justifications for planning and a theory of zoning" Progress in Planning $48161-246$

Lake R, 1993, "Rethinking NIMBY" Journal of the American Planning Association 59 87-93 
Lee T R, 1989, "Social attitudes and radioactive waste management" Radioactive Waste Management The 5th European Summer School, IBC Technical Services Ltd, London

Lo Piccolo F, Thomas H, 2001, "Legal discourse, the individual and the claim for quality in British planning" Planning Theory and Practice 2(2) 187-201

Loveland I, 2001, "The compatibility of the land use planning system with article 6 of the ECHR" Journal of Planning and Environmental Law May, 535-548

Low N, Gleeson B, 1999, "Geography, justice and the limits to rights", in Journeys in a Moral Terrain Eds J D Proctor, D M Smith (Routledge, London) pp 30-43

Lowndes V, Pratchett L, Stoker G, 2001a, "Trends in public participation: part 1-local government perspectives" Public Administration 79205 - 222

Lowndes V, Pratchett L, Stoker G, 2001b, “Trends in public participation: part 2-citizens' perspectives" Public Administration $79445-455$

McAuslan J P, 1980 The Ideologies of Planning Law (Pergamon, Oxford)

McAvoy G E, 1999 Controlling Technocracy: Citizen Rationality and the NIMBY Syndrome (Georgetown University Press, Washington, DC)

McCracken R, Jones G, 2003, "The Aarhus convention" Journal of Planning and Environmental Law July, $802-811$

McKeown B, Thomas D, 1988 Q-methodology (Sage, London)

Mackie J L, 1984, “Can there be a right-based moral theory?", in Theories of Rights Ed. J Waldron (Oxford Univerity Press, Oxford) pp $168-181$

Maurici J, 2002, "Human rights update: part 1" The Planning Inspectorate Journal 2512 - 16

Maurici J, 2003, "Human rights update: part 2" The Planning Inspectorate Journal 26 9-15

Miller C, 1998 Environmental Rights: Critical Perspectives (Routledge, London)

Miller D, 1995, "Citizenship and pluralism" Political Studies 43432 - 450

Monbiot G, 2000 Captive State: The Corporate Takeover of Britain (Macmillan, London)

Morello-Frosch R A, 2002,"Discrimination and the political economy of environmental inequality" Environment and Planning C: Government and Policy 20 477-496

Morrell D, 1987, "Siting and the politics of equity", in Resolving Locational Conflict Ed. R W Lake (CUPR Press, New Brunswick, NJ) pp $117-136$

O’Neill O, 2000 Bounds of Justice (Cambridge University Press, Cambridge)

Parker G, 1999, "Rights, symbolic violence, and the micropolitics of the rural: the case of the Parish Paths Partnership scheme" Environment and Planning A 31 1207-1222

Parker G, Ravenscroft N, 2001, "Land, rights and the gift: the countryside and Rights of Way Act 2000 and the negotiations of citizenship" Sociologia Ruralis 41381 - 398

Paton H J, 1948 The Moral Law (Hutchinson, London)

Pattie C, Seyd P, Whiteley P, 2003a, "Civic attitudes and engagment in modern Britain" Parliamentary Affairs $\mathbf{5 6} 616-633$

Pattie C, Seyd P, Whiteley P, 2003b, "Citizenship and civic engagment: attitudes and behaviour in Britain" Political Studies $51443-468$

Pearce B J, 1981, "Property rights vs. development control: a preliminary evaluation of alternative planning instruments" Town Planning Review 4541 - 60

Pearce B J, 1984, "Development control: a 'neighbourhood protection service'?" The Planner May, $8-11$

Pence G, 1993, "Virtue theory", in A Companion to Ethics Ed. P Singer (Blackwell, Oxford) pp $249-258$

Pennington M, 2000 Planning and the Political Market (Althlone Press, London)

Phelps N C, Tewdwr-Jones M, 2000, "Scratching the surface of collaborative and associative governance: identifying the diversity of social action in institutional capacity building" Environment and Planning A $32111-130$

Pløger J, 2001, "Public participation and the art of governance" Environment and Planning B: Planning and Design $28219-241$

Rabe B G, 1994 Beyond NIMBY (Brookings Institution Press, Washington, DC)

RCEP, 2002 Twenty-third Report: Environmental Planning Cm 5459, Royal Commission on Environmental Pollution (The Stationery Office, London)

Reade E, 1987 British Town and Country Planning (Open University Press, Milton Keynes, Bucks)

Richardson T, 1996, "Foucaldian discourse: power and truth in urban and regional policy making" European Planning Studies 4 279-292

Richardson T, 2002, "Freedom and control in planning using discourse in the pursuit of reflexive practice" Planning Theory and Practice $3353-361$ 
Rydin Y, Pennington M, 2000, "Public participation and local environmental planning: the collective action problem and the potential of social capital" Local Environment 5 153-169

Sanderson I, 1999, "Participation and democratic renewal: from 'instrumental' to 'communicative rationality?" Policy and Politics $27325-341$

Searing D D, Johnston-Conover P, Crewe I, 2003, "Citizenship in the age of liberalism" Parliamentary Affairs $56634-651$

Select Committee, 2000, "Thirteenth report: the Planning Inspectorate and public enquiries, minutes of evidence", Select Committee on Environment, Transport and Regional Affairs, House of Commons, London

Shestack J J, 1998, "The philosophic foundations of human rights" Human Rights Quarterly 20 $201-234$

Stammer N, 1993, "Human rights and power" Political Studies 4170 - 82

Stoker G, 1997, "Local political participation", in New Perspectives on Local Governance: Reviewing the Research Evidence Eds H Davies, C Skelcher, M Clarke, M Taylor, K Young, N Rao, G Stoker (Joseph Rowntree Trust, York) pp 157 - 196

Stone C D, 1974 Should Trees Have Standing? Towards Legal Rights for Natural Objects (William Kaufman, Los Altos, CA)

Taylor N, 1994, "Environmental issues and the public interest", in Values and Planning Ed. H Thomas (Avebury, Aldershot, Hants) pp $87-115$

Thomas H, 1996, "Public participation and planning", in British Planning Policy in Transition: Planning in the Major Years Ed. M Tewdwr-Jones (UCL Press, London) pp 159-188

Webster C, 1998, "Public choice, pigouvian and coasian planning theory" Urban Studies 35 $53-75$

Weissbrodt D, 1988, "Human rights: a historical perspective”, in Human Rights Ed. P Davies (Routledge, London) pp 1-20

Weston B H, 1984, "Human rights" Human Rights Quarterly 6257 - 283

Winkley R, 2002, "Coalition calls for third party rights" Planning 11 January, page 1

Wolsink M, 1994, "Entanglement of interests and motives: assumptions behind the NIMBY-theory of facility siting" Urban Studies $31851-866$

Yiftachel O, Huxley M, 2000, "Debating dominance and relevance: notes on the 'communicative turn' in planning theory" International Journal of Urban and Regional Research 24 907-913

Young I M, 1990 Justice and the Politics of Difference (University Press, Princeton, NJ 